\title{
Characterization of Chitotriosidase Enzyme Activity in the Serum of the American Alligator (Alligator mississippiensis)
}

\author{
Kenneth Kidder, Rodolfo Falconi, Mark Merchant* \\ Department of Chemistry, McNeese State University, Lake Charles, USA \\ Email: *mmerchant@mcneese.edu
}

How to cite this paper: Kidder, K., Falconi, R. and Merchant, M. (2018) Characterization of Chitotriosidase Enzyme Activity in the Serum of the American Alligator (Alligator mississippiensis). Advances in Biological Chemistry, 8, 81-90.

https://doi.org/10.4236/abc.2018.85007

Received: August 17, 2018

Accepted: October 7, 2018

Published: October 10, 2018

Copyright ( $\odot 2018$ by authors and Scientific Research Publishing Inc. This work is licensed under the Creative Commons Attribution International License (CC BY 4.0).

http://creativecommons.org/licenses/by/4.0/

\begin{abstract}
Chitotriosidase (ChT) is an endoglucosaminidase enzyme that cleaves chitinous substrates and has been strongly associated with innate immune activity and the ability to identify non-selftissues. This enzyme activity was detected and characterized the serum from the American alligator (Alligator mississippiensis) using a fluorometric probe. Alligator serum exhibited volume-dependent activity, with activity $(2.1 \pm 0.3 \mu \mathrm{mol} / \mathrm{min})$ observed at dilutions as low as a $1: 150$, and maximum activity $(5.2 \pm 0.6 \mu \mathrm{mol} / \mathrm{min})$ measured at a dilution of 1:30. Alligator serum ChT showed linear activity for approximately $20 \mathrm{~min}$, at which time activity decreased exponentially, presumably due to the depletion of substrate. In addition, the ChT activity in alligator serum was temperature-dependent with low activity at $5^{\circ} \mathrm{C}$, a sharp increase from $10^{\circ} \mathrm{C}-30^{\circ} \mathrm{C}$, and maximal activity from $30^{\circ} \mathrm{C}-40^{\circ} \mathrm{C}$. The activity was inhibited in the presence of water-soluble chitin, but not mannan, indicating the specificity of the enzyme. The presence of $\mathrm{ChT}$ in alligator serum is likely to be partially responsible for the potent innate immune system of these crocodylians, and particularly antifungal activities.
\end{abstract}

\section{Keywords}

Antifungal, Crocodilian, Crocodylian, Innate Immunity

\section{Introduction}

Chitin is a major component of the cell walls of fungi, and also in some bacteria, and the microfilarial sheath of parasitic nematodes [1] [2]. Chitinase enzymes are used by these organisms to remodel their outer walls. In addition, some organisms that do not have chitin polymers express chitinase enzymes to degrade 
chitin for carbon and energy [3], while others use it as a form of microbial and/or parasitic defense [4] [5] [6].

Chitotriosidase (ChT) is an endoglucosaminidase that cleaves, and exhibits transglycosylation activity towards chitin, a polymer of $\mathrm{N}$-acetyl-D-glucosamine present in the coatings of many pathogens [7]. It belongs to the family of 18 glycosyl hydrolases. Chitinases, in general, have been found in a variety of organisms and are believed to play an important role in innate immunity, especially against viral, bacterial, protozoan, fungal and nematode parasites [7] [8]. This enzyme has also been adapted by some organisms as a means of defense against pathogenic fungi and other chitinous pathogens [9] [10].

There are six recognized classes of chitinases, and ChT belongs to class III [11]. Chitotriosidase exists in two forms, a $50-\mathrm{kDa}$ precursor protein and a $39-\mathrm{kDa}$ active enzyme that is produced through proteolytic processing. The $50-\mathrm{kDa}$ protein consists of a C-terminal chitin-binding domain (hinge region) and a $39 \mathrm{kDa} \mathrm{N}$-terminal domain that has chitinase activity. Both forms are present in human serum [7] [8]. The $39-\mathrm{kDa}$ isoform is able to cleave chitotriose and also hydrolyzes colloidal chitin to yield chitobiose. The C-terminal domain also plays a role in processing colloidal chitin [8].

Chitotriosidase appears to be expressed in all mammalian species [12]. Studies conducted with goats and mice indicate a direct relationship between the lack of occurrence of pathogens and the presence of ChT activity in the serum. Studies among human populations also indicate a relationship between the exposure to pathogens and production of ChT [13]. Studies of Gaucher disease led to the isolation and identification of ChT [14]. Among human populations, a 24-base pair duplication in exon-10 of ChT activates a 3' splice and results in an enzymatically-inactive protein deficient in 29 amino acids [15]. The clinical result is an accumulation of glucosylceramide in the lysosomes of macrophages $(\mathrm{m} \Phi)$ which, in turn, accumulates in various tissues of the patient (Gaucher Disease) [14] [15]. Further investigations lead to the identification of AMCase (Acidic Mammalian Chitinase), which is present in two isoforms [16]. ACMase has an optimal $\mathrm{pH}$ of 2.3 and is capable of cleaving artificial and natural chitin-like substances [12] [14]. In populations lacking ChT, AMCase may offer significant resistance to chitin-based parasites as evidenced in natives of Papua New Guinea and India [17]. Among populations inhabiting environments with endemic parasitic diseases, the occurrence of non-functional ChT genes is much lower. Deficiencies in ChT production are common among human populations in France, Sicily and Asia, but are rare African populations [17].

In human studies, polymorphonuclear neutrophils (PMNs), not lymphocytes nor monocytes, were found to be the major source of ChT in blood. The enzyme is selectively expressed and released upon specific stimuli by human PMNs as well as $m \Phi-a$ macrophage produced by the differentiation of monocytes. Granulocyte macrophage colony-stimulating factors (GM-CSFs) induce the release of ChT from human PMNs, indicating the enzyme is not present in lysosome-like (blue staining) granules, but in specific granules [7]. When exposed to 
the proper stimuli, ChT is released. Serial plasma samples reveal plasma ChT and lactoferrin occur in parallel, but independent of neutrophil cell increase which occurs much later [7].

Due to its role in mammalian immunology, this study was conducted to characterize $\mathrm{ChT}$ in the American alligator (Alligator mississippiensis), an organism that lives in pathogen-laden environments. Only recently has attention been focused crocodylian immune systems (reviewed in [18]). The focus of this study was on the detection and characterization of ChT enzyme activity in the serum of the American alligator (Alligator mississippiensis).

\section{Materials and Methods}

Chemical and Biochemicals: 4-methylumbelliferyl- $\beta$-D-N, N', N"-triacetylchitotrioside (4 MU-chitotrioside), 4-methylumbelliferone (4-MUB), and glycine were purchased from Sigma-Aldrich Chemical Co. (St. Louis, MO).

Collection of Samples: Alligators $(\mathrm{n}=12,190-243 \mathrm{~cm})$ were captured from a boat at night, using a spotlight and cable snares. Whole blood $(10-20 \mathrm{~mL}$, depending on the size of the alligator) was collected from the spinalvein using $18 \mathrm{~g}$ a needles and a $20 \mathrm{~mL}$ syringes as described by Zippel et al. [19]. The animals were released immediately after the collection of samples. All of the activities concerning the treatment of alligators were approved by the McNeese State University Animal Care and Use Committee.

Enzyme assays were conducted in quadruplicate. Alligator serum was diluted to six different titers $(0.5 \%$ to $12.5 \%, \mathrm{v} / \mathrm{v})$ using isotonic saline. To each $100 \mu \mathrm{L}$ of diluted serum sample, $100 \mu \mathrm{L}$ of $25 \mu \mathrm{M}$ 4-MU-chitotrioside, dissolved in citrate-phosphate buffer ( $\mathrm{pH}$ 5.2), was added to initialize the reaction, and allowed to proceed for $15 \mathrm{~min}$ at ambient room temperature. At the end of the $15 \mathrm{~min}$ incubation, one $\mathrm{mL}$ of stop solution (3M glycine- $\mathrm{NaOH}$ buffer, $\mathrm{pH} 10.6)$ was added and fluorescent activity was recorded.

An enzyme kinetics experiment was conducted by adding $4 \mathrm{~mL}$ of $25 \mu \mathrm{M}$ 4-MUB substrate, $200 \mu \mathrm{L}$ serum, $1.8 \mathrm{~mL}$ isotonic saline. At various times after the addition of substrate $(0,1,2,5,10,15,20,30,60 \mathrm{~min}), 150 \mu \mathrm{L}$ were withdrawn and placed in cuvettes containing one $\mathrm{mL}$ of stop solution. Time zero samples were withdrawn as soon as the substrate was added. Product formation was recorded in Horiba Jovin Yvon Fluoromax4fluorimeterat an excitation $\lambda$ of $365 \mathrm{~nm}$ (slit width $=2 \mathrm{~nm}$ ), and an emission $\lambda$ of $450 \mathrm{~nm}$ (slit width $=2 \mathrm{~nm}$ ).

Thermodynamic stability of alligator ChT activity was evaluated at a broad range of temperatures $\left(5^{\circ} \mathrm{C}-40^{\circ} \mathrm{C}\right)$. Alligator serum $(5 \mu \mathrm{L})$ diluted with $195 \mathrm{~mL}$ of isotonic saline was incubated with $25 \mu \mathrm{M}$ substrate, and the reaction was allowed to proceed for $15 \mathrm{~min}$. The reaction was halted with the addition of one $\mathrm{mL}$ of stop solution, and the fluorescent activity was measured as described above.

Statistics and Controls: The fluorescence resulting from each reaction was compared to a standard curve developed from the pure product (4-MUB), and 
the nmol of product formed for each assay were calculated. The fluorescent intensities for each sample were corrected for background by the subtraction of florescence measured in alligator serum devoid of substrate. Each data point represents a mean \pm standard deviation of four independent determinations. The results obtained from each experiment were subjected to analysis of variance using Schee's post hoc comparisons [20].

\section{Results}

Upon exposure of different volumes of serum derived from the American alligator (A. mississippiensis) alligator serum to the fluorogenic substrate 4 MU-chitotrioside, a positive relation of serum volume with ChT activity was observed. Enzyme activity effectively catalyzed the target substrate at $1.0 \mu \mathrm{L}$ of serum, producing $31.5 \pm 5.22 \mu$ moles of product. An increase to only $5 \mu \mathrm{L}$ of serum resulted in maximal activity $(78.3 \pm 8.43 \mu$ moles $)$ and remained constant $(\mathrm{p}>0.05)$ at higher volumes $(10-50 \mu \mathrm{L})$.The increase at low volumes $(\leq 5 \mu \mathrm{L})$ was nearly linear $\left(y=14.5 x+7.5, R^{2}=0.976\right)$, with $50 \%$ of maximal activity calculated to occur at $3.2 \mu \mathrm{L}$ of alligator serum.

The kinetic character of alligator serum ChT activity is shown in Figure 2. Alligator serum showed substantial ChT activity within one min of substrate addition $(17.0 \pm 0.3, \mathrm{p}<0.05)$ and maximal activity $(301 \pm 14.8 \mu \mathrm{mol})$ within $30 \mathrm{~min}$. The activity was observed to be relatively linear for the first $20 \mathrm{~min}$, with a slope of approximately $13 \mu$ moles of product generated per minute.

Figure 3 displays the ChT activity of alligator at a broad spectrum of temperatures $\left(5^{\circ} \mathrm{C}-40^{\circ} \mathrm{C}\right)$. The generation of product occurred slowly at low temperatures, as $43.0 \pm 4.9$ and $65.2 \pm 5.3 \mu \mathrm{mol}$ of product were generated at $5^{\circ} \mathrm{C}$ and $10^{\circ} \mathrm{C}$, respectively, but increased greatly from $10^{\circ} \mathrm{C}-30^{\circ} \mathrm{C}$. The maximal $\mathrm{ChT}$ remained constant from $30^{\circ} \mathrm{C}-40^{\circ} \mathrm{C}(\mathrm{p}>0.05)$.

The addition of various amounts of water-soluble chitin to serum from alligators decreased the ChT activity in a concentration-dependent manner (Table 1). The inclusion of a 5-, 20- and 100-fold molar excess of chitin, relative to the

Table 1. Effects of water-soluble chitin and mannose on ChT activity in alligator serum. The fluorogenic substrate (4-MU-chitotrioside) was incubated alone, or with an excess of water-soluble chitin or mannose. The results are presented as a mean \pm standard deviation for four independent determinations and are expressed in $\mu$ mol product formed. ${ }^{*}=$ statistically lower $(\mathrm{p}<0.01)$.

\begin{tabular}{ccc}
\hline Incubation & ChT Activity & \% Inhibition \\
\hline $1 \mathrm{mM} 4$-MU-chitotrioside & $21.6 \pm 5.3$ & - \\
$1 \mathrm{mM} 4$-MU-chitotrioside $+5 \mathrm{mM}$ chitin & $17.9 \pm 2.3$ & $67^{\star}$ \\
$1 \mathrm{mM} 4-\mathrm{MU}$-chitotrioside $+20 \mathrm{mM}$ chitin & $7.1 \pm 1.3^{*}$ & $92^{\star}$ \\
$1 \mathrm{mM} 4-\mathrm{MU}$-chitotrioside $+50 \mathrm{mM}$ chitin & $1.7 \pm 2.1^{\star}$ & 3 \\
$1 \mathrm{mM} 4-\mathrm{MU}$-chitotrioside $+20 \mathrm{mM}$ mannose & $21.0 \pm 3.5$ & 5 \\
\hline $\mathrm{mM} 4-\mathrm{MU}$-chitotrioside $+50 \mathrm{mM}$ mannose & $20.5 \pm 1.9$ & \\
\hline
\end{tabular}


fluorogenic chitinous substrate, resulted in a $17 \%, 67 \%$, and $92 \%$ decrease in ChT-mediated cleavage of the chitinous substrate, respectively. Furthermore, the addition of a 20- or 100-fold molar excess of mannan resulted in no change ( $p$ > $0.05)$ in ChT activity.

\section{Discussion}

Ectothermic vertebrates rely heavily on innate immunity as the major mechanism of host defense [21]. Innate immunity is relatively rapid and nonspecific in nature, relying on molecular pattern recognition to discriminate self from non-self tissues [22] [23]. Although American alligators have less-developed adaptive immune systems relative to endothermic vertebrates [24], they exhibit well-developed innate immune mechanisms (reviewed in [25]). It is thought that the biological cost of development and maintenance of adaptive immunity is a limiting factor for ectotherms [26]. Because ectotherms cannot regulate body temperature by internal mechanisms, they undergo seasonal shift in their biochemistry and physiology which is associated with environmental conditions, and constrains available mechanisms of immunity [27].

The addition of increasing volumes of alligator serum to enzyme assays resulted in more enzyme activity (Figure 1). The amount of product formed was parallel to that observed with serum from Caiman latirostris [28]. The shapes of the curves were virtually identical when serum from these two Alligatorids was used in ChT assays. Human serum ChT levels in normal patients have been reported to be similar [29]. The increase of $14.5 \mu$ moles of product formation per one $\mu \mathrm{L}$ of serum is extremely high and was similar to that produced by serum from the broad-snouted caiman [28], when standardized for substrate concentration. It is likely that the enzyme activity observed is due to the presence of

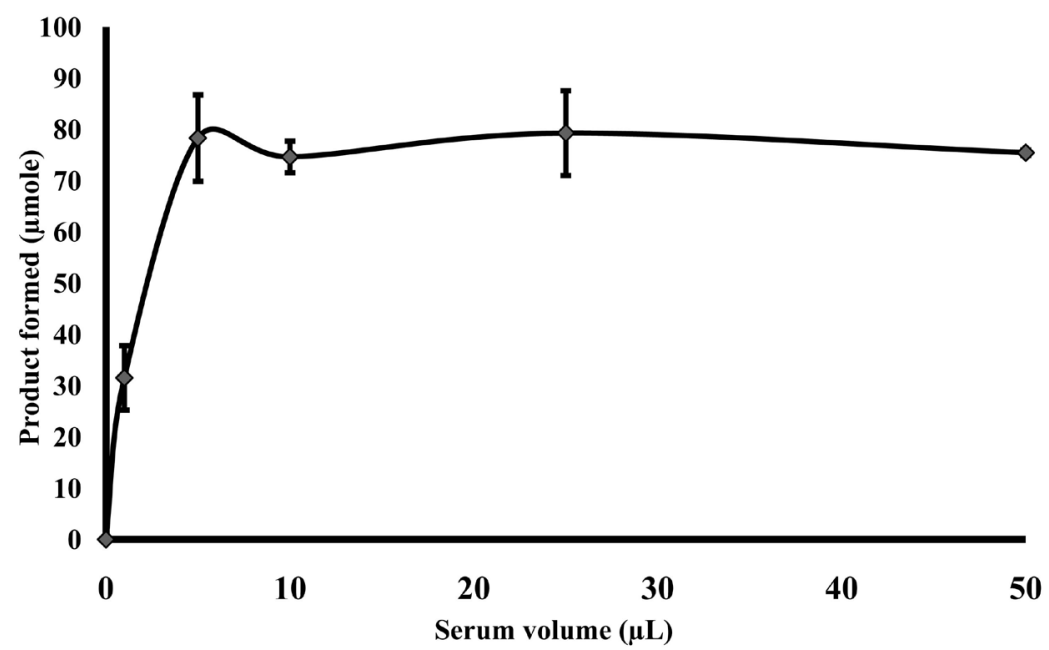

Figure 1. Relation of the volume of alligator serum with ChT activity. Difference volumes of alligator serum were incubated with the fluorogenic substrate, and the fluorescence product was measured at an excitation $\lambda$ of $365 \mathrm{~nm}$ ( slit width $=2 \mathrm{~nm}$ ), and an emission $\lambda$ of $450 \mathrm{~nm}$ (slit width $=2 \mathrm{~nm}$ ). The results are presented as a mean \pm standard deviation for four independent determinations and are expressed in $\mu$ mol product formed. 
ChT due to the fact that the activity could be inhibited by unlabeled chitin, but not by another polysaccharide such as mannan (Table 1).

The kinetic character of alligator ChT (Figure 2) was also very similar to that measured in the broad-snouted caiman [28]. Small volumes of serum $(2-5 \mu \mathrm{L})$ resulted in rapid accumulation of product. The rapid rise in accumulated fluorescent product is an indication of the high capacity for cleavage of chtinous substrates. These results seem to indicate that this enzyme activity in serum derived from alligators has the ability to rapidly compromise the structural integrity of microbes with chitinous outer cell walls.

The thermal profile of alligator ChT activity reflects the preferred body temperatures of these animals. Alligators thermoregulate to an internal body temperature of $31^{\circ} \mathrm{C}-32^{\circ} \mathrm{C}$ [30], where many physiological parameters such as cardiac function [31] and general metabolism [32], are optimized. In addition, many immunological parameters, such as serum complement [33], phospholipase $\mathrm{A}_{2}$ [34], and dipeptidyl peptidase IV [35] activities have been shown to exhibit comparable thermal characteristics. At temperatures higher than the preferred body temperature the activity $\mathrm{ChT}$ remains high (Figure 3 ). Alligators are known to exhibit a febrile response to infection, which is not controlled by internal biochemical mechanisms, but rather by basking behavior [36]. During this response, infected alligators achieve higher daily internal body temperature spikes relative to untreated animals or those injected with saline controls. It is notable that, at lower temperatures, the activity of alligator $\mathrm{ChT}$ in the plasma is depressed; however, at temperatures above $30^{\circ} \mathrm{C}$, the activity remains high (Figure $3)$. The potential function of this elevated internal body temperature during

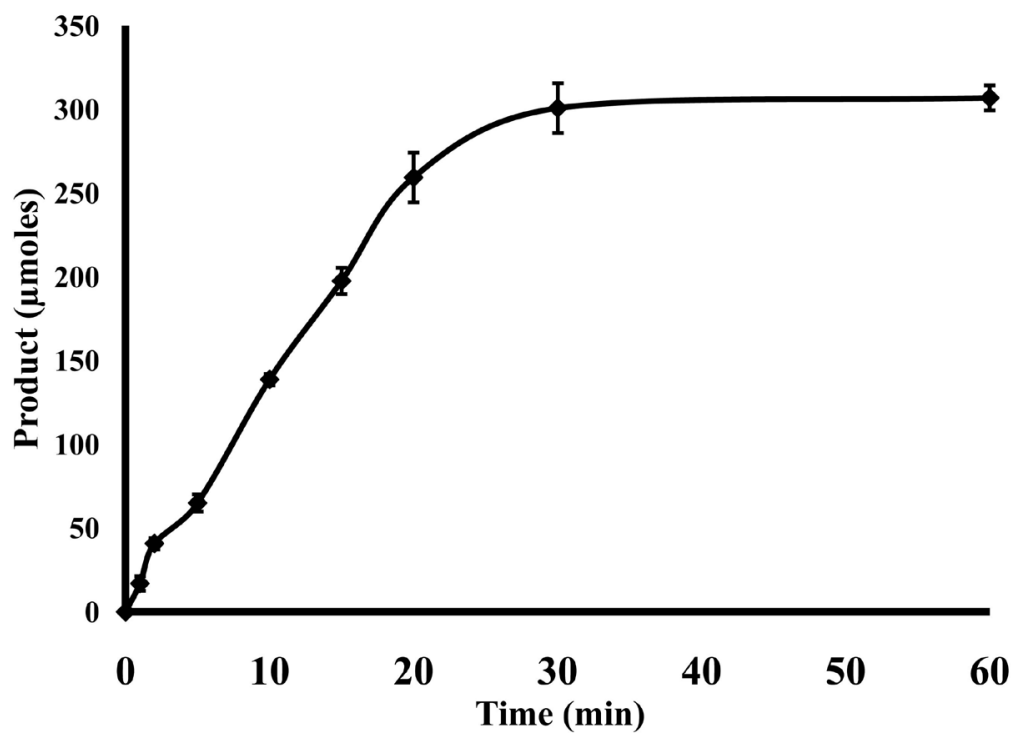

Figure 2. Kinetic profile of ChT activity at $25^{\circ} \mathrm{C}$. Alligator serum was incubated for different amounts of time with a fluorogenic substrate, and the fluorescence product was measured at an excitation $\lambda$ of $365 \mathrm{~nm}$ (slit width $=2 \mathrm{~nm}$ ), and an emission $\lambda$ of $450 \mathrm{~nm}$ (slit width $=2 \mathrm{~nm}$ ). The results are presented as a mean \pm standard deviation for four independent determinations and are expressed in $\mu$ mol product formed. 


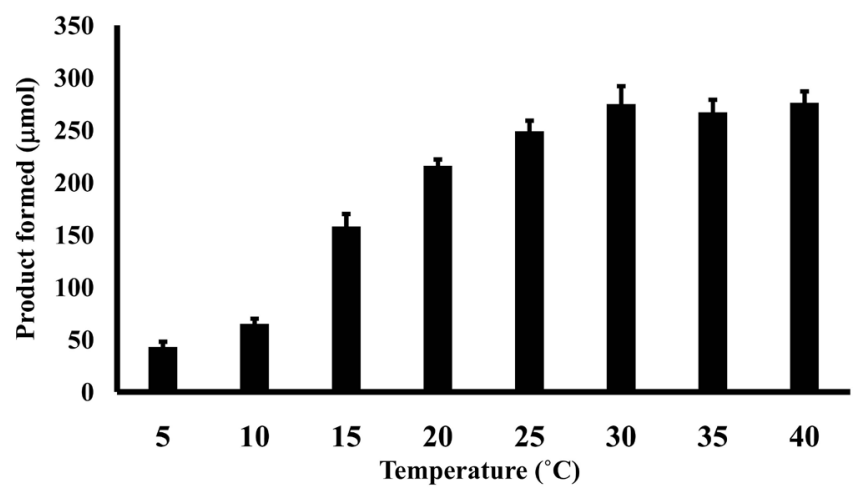

Figure 3. Thermal profile of alligator serum ChT activity. Alligator serum was incubated in the presence of fluorogenic substrate for one hour at different temperatures. The fluorescence product was measured at an excitation $\lambda$ of $365 \mathrm{~nm}$ (slit width $=2 \mathrm{~nm}$ ), and an emission $\lambda$ of $450 \mathrm{~nm}$ (slit width $=2 \mathrm{~nm}$ ). The results are presented as a mean \pm standard deviation for four independent determinations and are expressed in $\mu$ mol product formed.

infection might be to increase the temperature above the optimal growing range for pathogenic microbes while still maintaining a potent immune defense.

Alligators, like most crocodylians, spend appreciable amounts of time shuttling from terrestrial to aquatic environments in an attempt to regulate body temperature. This behavior results in these animals having moist skin much of the time, which would seem to be a suitable substrate for fungal colonization and growth. Because many fungi have chitinous outer membranes [37], ChT activity is thought to have evolved as an innate immune defense against infection by potentially pathogenic fungi [38] [39]. The high levels of circulating ChT activities in crocodylian blood may serve to protect against fungal infections.

\section{Acknowledgements}

The authors wish to thank Dr. Michael Berger, former Wildlife Division Director of the Texas Parks and Wildlife Department, for access to public lands on which to capture wild alligators. In addition, we thank Mr. Jim Sutherlin, former J. D. Murphree Wildlife Management Area manager, for his assistance and coordination of alligator captures on the refuge. This research was supported by the Louisiana Board of Regents Graduate Fellowship grant (LEQSF (2009-11)GFT-02), a National Science Foundation Research Commercialization/Educational Enhancement Plan, and a grant from the National Oceanic and Atmospheric Administration (NA08NOS4630474).

\section{Conflicts of Interest}

The authors declare no conflicts of interest regarding the publication of this paper.

\section{References}

[1] Araujo, A., Souto-Padron, T. and de Souza, W. (1993) Cytochemical Localization of 
Carbohydrate Residues in Microfilariae of Wuchereria bancrofti and Brugia malayi. Journal of Histochemistry \& Cytochemistry, 41, 571-578. https://doi.org/10.1177/41.4.8450196

[2] Fuhrman, J.A. and Plessens, W.F. (1985) Chitin Synthesis and Sheath Morphogenesis in Brugiamalayi microfilariae. Molecular and Biochemical Parasitology, 17, 93-104. https://doi.org/10.1016/0166-6851(85)90130-6

[3] Merzendorfer, H. and Zimoch, L. (2003) Chitin Metabolism in Insects: Structure, Function and Regulation of Chitin Synthases and Chitinases. Journal of Experimental Biology, 206, 4393-4412. https://doi.org/10.1242/jeb.00709

[4] Roberts, W.K. and Selitrennikoff, C. P. (1988) Plant and Bacterial Chitinases Differ in Antifungal Activity. Journal of Fish Biology, 24, 125-134.

[5] Sahai, A.S. and Manocha, M.S. (1993) Chitinases of Fungi and Plants: Their Involvement in Morphogenesis and Host-Parasite Interaction. FEMS Microbiology Reviews, 11, 317-338. https://doi.org/10.1111/j.1574-6976.1993.tb00004.x

[6] Lee, C., Da Silva, C., Lee, J., Hartl, D. and Elias, J. (2008) Chitin Regulation of Immune Responses: An Old Molecule with New Roles. Current Opinion in Immunology, 20, 684-689. https://doi.org/10.1016/j.coi.2008.10.002

[7] Van Eijk, M., van Roomen, C.P., Remnekma, G.H., Bussinl, A.P., Andrews, L., Blommaart, E.F., Sugr, A., Verhoeven, A.J., Boot, R.G. and Aerts, J.M. (2005) Characterization of Human Phagocyte-Derived Chitotriosidase, a Component of Innate Immunity. International Immunology, 17, 1505-1512.

https://doi.org/10.1093/intimm/dxh328

[8] Fusetti, Fabrizia, von Moeller, Holger, Houston, D., Rozeboom, H., Dijstra, B., Boot, R., Aerts, J. and van Aalten, D. (2002) Structure of Human Chitotriosidase. The Journal of Biological Chemistry, 277, 25537-25544. https://doi.org/10.1074/jbc.M201636200

[9] Matroodi, S., Motallebi, M., Zamani, M. and Moradyar, M. (2013) Designing a New Chitinase with More Chitin Binding and Antifungal Activity. World Journal of Microbiology and Biotechnology, 29, 1517-1523. https://doi.org/10.1007/s11274-013-1318-0

[10] Verwer, P., Kate, M., Falcone, F., Morroll, S., Verbruh, H., Bakker, I. and van de Sande, W. (2013) Evidence Supporting a Role for Mammalian Chitinases in Efficacy of Caspofungin against Experimental Aspergillosis in Immunocompromised Rats. PLoS ONE, 8, e75848. https://doi.org/10.1371/journal.pone.0075848

[11] Patil, R.S., Ghormade, V. and Deshpande, M.V. (2000) Chitinolytic Enzymes: An Exploration. Enzyme and Microbial Technology, 26, 473-483. https://doi.org/10.1016/S0141-0229(00)00134-4

[12] Bussink, A.P., Speijer, D., Aerts, J.M.F.G. and Boot, R.G. (2007) Evolution of Mammalian Chitinas(-Like) Members of Family 18 Glycosyl Hydrolases. Genetics, 177, 959-970. https://doi.org/10.1534/genetics.107.075846

[13] Agrüello, A, Castro, N., Batista, M., Moreno-Indias, I., Morales-delaNuez, A., Sanchez-Marcias, D., Quesada, E. and Capote, J. (2008) Chitotriosidase Activity in Goat Blood and Colostrum. Journal of Dairy Science, 91, 2067-2070. https://doi.org/10.3168/jds.2007-0826

[14] Hollak, C.E.., van Weely, S., van Oers, M.H. and Aerts, J.M. (1994) Marked Elevation of Plasma Chitotriosidase Activity. Journal of Clinical Investigation, 93, 1288-1292. https://doi.org/10.1172/JCI117084

[15] Seibold, M.., Donnelly, S., Solon, M., Innes, A., Woodruff, P., Boot, R., Burchard, E. and Fahy, J. (2008) Chitotriosidase Is the Primary Active Chitinase in the Human 
Lung and Is Modulated by Genotype and Disease. Journal of Allergy and Clinical Immunology, 122, 944-950. https://doi.org/10.1016/j.jaci.2008.08.023

[16] Boot, R.G., Blommaart, E., Swart, E., Ghauharali-van der Vlugt, K., Bijl, N., Moe, C., Place, A. and Aerts, J.M. (2001) Identification of a Novel Acidic Mammalian Chitinase Distinct from Chitotriosidase. The Journal of Biological Chemistry, 276, 6770-6778. https://doi.org/10.1074/jbc.M009886200

[17] Lee, P., Waalen, J., Smargon, A. and Beutler, E. (2007) Human Chitotriosidase Polymorphisms G345R and A442V Associated with Reduced Enzyme Activity. Blood Cells, Molecules and Diseases, 39, 353-350.

https://doi.org/10.1016/j.bcmd.2007.06.013

[18] Merchant, M. (2013) Chapter 18: From Marshes to Medicine: The Role of Immunological Defense in the American Alligator. In: Lutterschmidt, W., Ed., Reptiles in Research: Investigations of Ecology, Physiology, and Behavior from Desert to Sea, Nova Science Publishers Inc., Hauppauge, New York, 351-365.

[19] Zippel, K.C., Lillywhite, H.B. and Mladnich, C.R. (2003) Anatomy of the Crocodilian Spinal Vein. Journal of Morphology, 258, 327-335. https://doi.org/10.1002/jmor.10156

[20] Tamhane, C. and Dunlop, D.D. (2000) Scheffe's Method for General Contrasts. In: Statistics and Data Analysis: From Elementary to Intermediate, Prentice Hall, Upper Saddle River, 477.

[21] Flajnik, M. and Kasahara, M. (2010) Origin and Evolution of the Adaptive Immune System: Genetic Events and Selective Pressures. Nature Reviews Genetics, 11, 47-59. https://doi.org/10.1038/nrg2703

[22] Kawai, T. and Akira, S. (2010) The Role of Pattern Recognition Receptors in Innate Immunity: Update on Toll-Like Receptors. Nature Immunology, 11, 373-384. https://doi.org/10.1038/ni.1863

[23] Medzhitov, R. and Janeway, C.S.J. (2000) Innate Immune Recognition Mechanisms and Pathways. Immunological Reviews, 173, 89-97. https://doi.org/10.1034/j.1600-065X.2000.917309.x

[24] Cuchens, M.A. and Clem, L.W. (1979) Phylogeny of Lymphocyte Heterogeneity. IV. Evidence for T-Like and B-Like Cells in Reptiles. Developmental \& Comparative Immunology, 3, 465-475. https://doi.org/10.1016/S0145-305X(79)80042-7

[25] Merchant, M. and Murray, C. (2018) Chapter 4: Thermal Regulation and Innate Immunology of the American Alligator. In: Eversole, C. and Henke, S., Eds., American Alligators. Habitats, Behaviors, and Threats, Nova Science Publishers Inc. Hauppauge, New York, 79-96.

[26] Zimmerman, L.M., Vogel, L.A. and Bowden, R.M. (2010) Understanding the Vertebrate Immune System: Insights from the Reptilian Perspective. Journal of Experimental Biology, 213, 661-671. https://doi.org/10.1242/jeb.038315

[27] Sandmeier, F. and Tracy, R. (2014) The Metabolic Pace-of-Life Model: Incorporating Ectothermic Organisms into the Theory of Vertebrate Ecoimmunology. Integrative and Comparative Biology, 54, 387-395. https://doi.org/10.1093/icb/icu021

[28] Siroski, P., Poletta, G., Parachu'-Marco, V., Ortega, H. and Merchant, M. (2014) Presence of Chitinase Enzymes in Crocodilians. Acta Herpetologica, 9, 139-146.

[29] Artieda, M., Cenarro, A., Ganan, A., Jerico, I., Gonzalvo, C., Casado, J., Vitoria, I., Puzo, J., Pocovi, M. and Civeira, F. (2003) Serum Chitotriosidase Activity Is Increased in Subjects with Atherosclerosis Disease. Arteriosclerosis, Thrombosis, and Vascular Biology, 23, 1645-1652. https://doi.org/10.1161/01.ATV.0000089329.09061.07 
[30] Johnson, C.R., Voigt, W.G. and Smith, E.N. (1978) Thermoregulation in Crocodilians III. Thermal Preferenda, Voluntary Maxima, and Heating and Cooling Rates in the American Alligator, Alligator mississipiensis. Zoological Journal of the Linnean Society, 62, 179-188. https://doi.org/10.1111/j.1096-3642.1978.tb01036.x

[31] Wilber, C. (1960) Effect of Temperature on the Heart in the Alligator. American Journal of Physiology, 198, 861-863. https://doi.org/10.1152/ajplegacy.1960.198.4.861

[32] Coulson, R.A., Herbert, J. and Coulson, T. (1989) Biochemistry and Physiology of Alligator Metabolism in Vivo. American Zoologist, 29, 921-934. https://doi.org/10.1093/icb/29.3.921

[33] Merchant, M., Roche, C., Sweeney, A. and Elsey, R. (2005) Identification of Serum Complement Activity in the American Alligator (Alligator mississippiensis). Comparative Biochemistry and Physiology_Part B, 141, 281-288. https://doi.org/10.1016/j.cbpc.2005.03.009

[34] Merchant, M., Heard, R. and Monroe, C. (2009) Characterization of Phospholipase $\mathrm{A}_{2}$ Activity in Serum of the American Alligator (Alligator mississippiensis). Journal of Experimental Zoology Part A, 311, 662-666. https://doi.org/10.1002/jez.553

[35] Merchant, M., Monroe, C. and Falconi, R. (2009) Characterization of Dipeptidyl Peptidase IV Enzyme Activity in the Blood of the American Alligator (Alligator mississippiensis). Comparative Biochemistry and Physiology_Part B, 154, 341-345. https://doi.org/10.1016/j.cbpb.2009.07.010

[36] Merchant, M., Williams, S., Troclair, P. and Elsey, R.M. (2007) Febrile Response in the American Alligator (Alligator mississippiensis). Comparative Biochemistry and Physiology_Part A, 148, 921-925. https://doi.org/10.1016/j.cbpa.2007.09.016

[37] Cabib, E., Bowers, B., Sburlati, A. and Silverman, S.J. (1988) Fungal Cell Wall Synthesis: The Construction of a Biological Structure. Microbiology Journal, 5, 370-375.

[38] Chen, L., Shen, Z. and Wu, J. (2008) Expression, Purification and in Vitro Antifungal Activity of Acidic Mammalian Chitinase against Candida albicans, Aspergillus fumigatus and Trichophyton rubrum Strains. Clinical and Experimental Dermatology, 34, 55-60. https://doi.org/10.1111/j.1365-2230.2008.03092.x

[39] Vega, K. and Kalkum, M. (2012) Chitin, Chitinase Responses, and Invasive Fungal Infections. International Journal of Microbiology, 2012, Article ID: 920459. https://doi.org/10.1155/2012/920459 